\title{
Generation Mean Analysis for Yield, Yield Components and MYMV Disease Scores in Blackgram [Vigna mungo (L).Hepper]
}

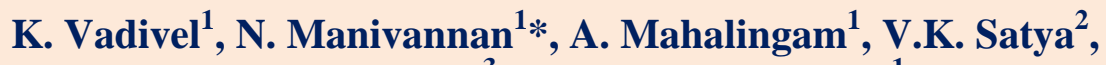 \\ C. Vanniarajan ${ }^{3}$ and V.R. Saminathan ${ }^{1}$ \\ ${ }^{1}$ National Pulses Research Center, Tamil Nadu Agricultural University, \\ Vamban Colony-622303, TamilNadu, India \\ ${ }^{2}$ Krishi Vigyan Kendra, Tamil Nadu Agricultural University, Tindvanam, TamilNadu, India \\ ${ }^{3}$ Department of Plant Breeding and Genetics, Agricultural College and Research Institute, \\ Tamil Nadu Agricultural University, Madurai, TamilNadu, India \\ *Corresponding author
}

\section{A B S T R A C T}

\section{Keywords}

Blackgram, Gene action, Generation mean analysis, MYMV disease, Seed yield

Article Info

Accepted:

17 April 2019

Available Online:

10 May 2019

\begin{abstract}
Generation mean analysis was employed in two crosses viz., MDU 1 x Mash 114 and MDU 1 x Mash 1008 of balckgram to partition the mean into various components viz., additive, dominance and epistasis. Traits viz., number of clusters per plant, pod length, and number of seeds per pod were controlled by additive gene action in the cross MDU $1 \mathrm{x}$ Mash 114. The additive as well as additive $\mathrm{x}$ additive type of gene action were in control of seed yield per plant, MYMV disease scores and most of yield components in the cross MDU 1 x Mash 114. Hence selection at later generation is effective to improve these traits. In case of MDU 1 x Mash 1008 also, most of the traits except seed yield per plant, number branches per plant and number of cluster per plant had epistatsic model. Hence selection needs to be postponed to later generation. Hence based on gene action, the cross MDU $1 \mathrm{x}$ Mash 114 may be utilized to evolve high yielding plants with MYMV disease resistant genotypes.
\end{abstract}

\section{Introduction}

Blackgram (Vigna mungo (L.) Hepper) is an important food legume crop of Indian subcontinent. It is an important short duration crop and widely cultivated in India. It gives us an excellent source of easily digestible good quality protein and ability to restore the fertility of soil through symbiotic nitrogen fixation. Seeds are highly nutritious with protein $(24-26 \%)$, carbohydrates $(60 \%)$, fat (1.5\%), minerals, amino acids and vitamins. The biological value improves greatly, when wheat or rice is combined with blackgram because of the complementary relationship of the essential amino acids such as arginine, leucine, lysine, isoleucine, valine and phenylalanine, etc. (Mehra et al., 2016). In India, the area comes under blackgram is about 4.50 million hectares with the 
production of 3.23 million tonnes (Annonymous, 2018). Mungbean Yellow Mosaic Virus (MYMV) is a significant biotic stress causing profound yield loss in blackgram. MYMV belongs to the genus Begomovirus and transmitted by the vector whitefly, Bemisia tabaci. Yield loss due to this disease varies from 5 to 100 per cent depending upon disease severity, susceptibility of cultivars and population of whitefly (Nene, 1972). The low yield levels are due to several biotic and abiotic factors. The estimates of genetic components of variation would be very useful to adopt suitable breeding method and to find the appropriate generation for the improvement of traits (Khattak et al., 2001). With these backgrounds, the present investigation was carried out to find out the gene action for seed yield, yield components and MYMV disease score through generation mean analysis.

\section{Materials and Methods}

The experiment was conducted at National Pulses Research Centre, Vamban during kharif 2018 in two crosses of blackgram viz., MDU 1 x Mash 114 and MDU 1 x Mash 100. MDU 1 is a high-yielding popular blackgram variety grown in Tamil Nadu, but highly susceptible to Mungbean Yellow Mosaic Virus (MYMV) disease. The variety was released during 2014 by Agriculture collage and Research Institute, Tamil Nadu Agricultural University, Madurai for commercial cultivation. Mash 114 and Mash 1008 are varieties released by Punjab Agricultural University, Ludhiana and resistant to MYMV disease. Five generations viz., $\mathrm{P}_{1}, \mathrm{P}_{2}, \mathrm{~F}_{1}, \mathrm{~F}_{2}$ and $\mathrm{F}_{3}$ of these two crosses were evaluated during kharif 2018. Populations were screened for MYMV disease resistance through infector row method. Susceptible variety CO 5 and MDU 1 were used in the infector row. Recommended agronomic packages of practices were followed to raise the crop. Observations were recorded on individuals plant in respect of plant height $(\mathrm{cm})$, number of branches per plant, number of clusters per plant, number of pods per cluster, number of pods per plant, pod length $(\mathrm{cm})$, number of seeds per pod, 100-seed weight (g), MYMV disease score at 45 DAS, MYMV disease score at 60 DAS and seed yield per plant $(\mathrm{g})$. Mean of five generations viz., $\mathrm{P}_{1}, \mathrm{P}_{2}, \mathrm{~F}_{1}, \mathrm{~F}_{2}$ and $\mathrm{F}_{3}$ were used to estimate genetic parameters. The MYMV disease score was recorded on 45 and 60 DAS, by using phenotype rating scale from 1 (resistant) to 9 (highly susceptible) (Table 1), as suggested by Singh et al., (1995). Scaling test was conducted as suggested by Mather (1949). The adequacy of simple additive-dominance model was detected by employing $\mathrm{C}$ and $\mathrm{D}$ scaling test suggested by Mather and Jinks (1971). The additive-dominance model was considered inadequate when any one of the two scales was found to deviate significantly from zero. Genetic parameters were estimated following Hayman (1958).

\section{Results and Discussion}

A good knowledge on the genetic systems controlling expression of the characters facilitates the choice of the most efficient breeding and selection procedure (Gopikannan and Ganesh, 2013; Mangaldeep et al., 2015). The generation mean analysis was adopted to detect non-allelic interaction component of the mean of the phenotypic distribution. The results of scaling test and genetic parameters in each cross were presented in (Table 2 and 3 ).

\section{Plant height (cm)}

The estimate of scaling test revealed that both crosses MDU1 x Mash 114 and MDU1 x Mash 1008 showed significance for the scale D. Additive (d), dominance (h) and additive $\mathrm{x}$ 
additive (i) effects were significant in the cross MDU1 x Mash 114. Additive (d), dominance (h) and dominance $\mathrm{x}$ dominance (l) components were significant in the cross MDU1 x Mash 1008. The results indicated that additive, dominance and epistatic component of additive $\mathrm{x}$ additive gene action are involved in controlling this trait in MDU1 $\mathrm{x}$ Mash 114. However in case of MDU1 $\mathrm{x}$ Mash 1008, in addition to additive, dominance components, epistatic component of dominance $\mathrm{x}$ dominance was also important. Similarly Kanchana Rani (2008) and Thamodharan et al., (2015) recorded additive and non-additive gene action respectively.

\section{Number of branches per plant}

The scaling test revealed that scale $\mathrm{C}$ was significant in both crosses MDU1 x Mash 114 and MDU1 x Mash 1008. In cross MDU1 x Mash 114, components additive (d) and additive $\mathrm{x}$ additive (i) components were significant. It indicated the presence of additive, additive $\mathrm{x}$ additive gene action in this cross. In case of MDU1 x Mash 1008, components on dominance $\mathrm{x}$ dominance (l) was significant. It indicated the presence of dominance $\mathrm{x}$ dominance type of gene actions in the cross. Same results of additive and nonadditive gene action were given by Latha et al., (2018) and Prasad and Murugan (2015) respectively.

\section{Number of clusters per plant}

The scaling test showed the significance of the scale D in the cross MDU1 x Mash 1008 for number of cluster per plant, which implied the inadequacy of the simple additivedominance model for this cross. In case of MDU1 x Mash 114, scaling test indicated that roll of simple additive dominance action. In case of MDU1 x Mash 114, additive (d) component alone was significant. In case of
MDU1 x Mash 1008, additive x additive (i) and dominance $\mathrm{x}$ dominance (l) components were significant. The results indicated that epistatic gene action plays a major role in MDU1 x Mash 1008 and additive gene action in MDU 1 x Mash 114. Similarly additive gene action was reported by Kanchana rani (2008) and Latha et al., (2018). Non-additive gene action was reported by Thamodharan et al., (2015).

\section{Number of pods per cluster}

In case of number of pods per clusters showed significant for D scale in the cross MDU1 $\mathrm{x}$ Mash 114 and significance of the scales $C$ and $\mathrm{D}$ in MDU1 $\mathrm{x}$ Mash 1008. If indicated the epistatic model in both crosses. In case of MDU1 x Mash 114 additive $x$ additive (i) and dominance $\mathrm{x}$ dominance (1) components were significant. The results indicated that epistatic gene action plays a major role in MDU1 $\mathrm{x}$ Mash 114. However in the cross MDU1 $x$ Mash 1008, additive (d), dominance (h), additive $\mathrm{x}$ additive (i) and dominance $\mathrm{x}$ dominance (l) components were significant. The results indicated that additive and epistatic gene action plays a major role in the cross MDU1 x Mash 1008. Non-additive gene action was reported by Thamodharan et al., (2015).

\section{Number of pods per plant}

The scaling test revealed that scale $\mathrm{D}$ was significant in the cross MDU1 x Mash 114 and MDU1 x Mash 1008 were significant. In both crosses viz., MDU1 x Mash 114 and MDU1 x Mash 1008, components of additive (d), additive $\mathrm{x}$ additive (i) and dominance $\mathrm{x}$ dominance (l) were significant. It indicated the presence of additive and epistatic type of gene actions in both crosses. Similarly Kanchana Rani (2008) and Panigrahi et al., (2015) recorded additive and non-additive gene action respectively. 


\section{Pod length $(\mathrm{cm})$}

The scaling test showed the significance of the scale $\mathrm{C}$ in the cross MDU1 x Mash 1008 for pod length, which in turn suggested the importance of epistatic gene action in the inheritance of this trait. In case of MDU1 $x$ Mash 114, simple additive dominance action plays a major role. In case of MDU1 x Mash 114, additive (d) component alone was significant and indicated additive gene action. However in the cross MDU1 x Mash 1008 additive (d), additive $\mathrm{x}$ additive (i) and dominance $\mathrm{x}$ dominance (l) components were significant. It indicated the presence of additive, as well as epistatic type of gene actions in this cross. Similarly Kanchana rani (2008) and Latha et al., (2018) recorded additive and non-additive gene action respectively.

\section{Number of seeds per pod}

Simple additive-dominance model were adequate in this cross MDU1 x Mash 114 alone. However, the cross MDU1 $x$ Mash 1008 recorded significance for both scales C and $\mathrm{D}$, revealing the inadequacy of simple additive-dominance model. Dominance component in cross MDU1 x Mash 114 was positive and significant and indicated that dominance gene action was prominent. In case of MDU1 x Mash 1008, additive (d), dominance (h), additive $\mathrm{x}$ additive (i) and dominance $\times$ dominance (1) components were significant. The results indicated that additive as well as epistatic gene action plays major role in this cross. Similarly additive and nonadditive gene action was observed by Zubair et al., (2007) and Latha et al., (2018) respectively.

\section{0-seed weight (g)}

Significance of the scales C and D implied in sufficiency of simple additive-dominance model for both crosses. Dominance gene effect in cross MDU1 $x$ Mash 114 was significant. The results indicated that dominance gene action and other non genetic effects were prominent in MDU1 x Mash 114. In cross MDU1 x Mash 1008, components additive (d) and additive $x$ additive (i) components were significant. It indicated the presence of additive and epistatic gene action plays major role in this cross. Similarly additive gene action was reported by Zubair et al., (2007). Non-additive gene action was reported by Panigrahi et al., (2015). '

Table.1 MYMV disease scoring

\begin{tabular}{|c|c|c|}
\hline Grade & Description & Reaction \\
\hline 1 & No visible symptoms on leaves & Free \\
\hline 2 & $\begin{array}{l}\text { Small yellow specks with restricted spread covering } 0.1-5 \% \text { leaf } \\
\text { area }\end{array}$ & Highly Resistant (HR) \\
\hline 3 & Mottling of leaves covering 6-10\% leaf area & Resistant ( R) \\
\hline 4 & Yellow mottling covering $11-15 \%$ leaf area & Moderately resistant (MR) \\
\hline 5 & Yellow mottling and discolouration of $15-20 \%$ leaf area & Moderately susceptible MS) \\
\hline 6 & Yellow coloration of $21-30 \%$ leaves and yellow pods & Susceptible (S) \\
\hline 7 & $\begin{array}{l}\text { Pronounced yellow mottling and discoloration of leaves and pods, } \\
\text { reduction in leaf size and stunting of plants covering 30-50\% of } \\
\text { foliage }\end{array}$ & Susceptible (S) \\
\hline 8 & $\begin{array}{l}\text { Severe yellow discoloration of leaves covering } 50-75 \% \text { of foliage, } \\
\text { stunting of plants and reduction in pod size }\end{array}$ & Highly susceptible (HS) \\
\hline 9 & $\begin{array}{l}\text { Severe yellowing of leaves covering above of foliage, stunting of } \\
\text { plants and no pod formation }\end{array}$ & Highly susceptible (HS) \\
\hline
\end{tabular}


Table.2 Scaling test and estimates of genetic parameters for various characters in blackgram the cross MDU1 x Mash 114

\begin{tabular}{|c|c|c|c|c|c|c|c|}
\hline \multirow[t]{2}{*}{ Character } & \multicolumn{2}{|c|}{ Scales } & \multicolumn{5}{|c|}{ Parameters } \\
\hline & $\mathbf{C}$ & D & $\mathbf{m}$ & d & h & $\mathbf{i}$ & l \\
\hline Plant height (cm) & $1.04 \pm 5.61$ & $14.70 * \pm 6.36$ & $28.43 * * \pm 1.08$ & $10.18 * * \pm 0.60$ & $-13.11 * * \pm 4.60$ & $10.73 * \pm 4.23$ & $18.21 \pm 12.50$ \\
\hline Number of branches per plant & $1.28 * \pm 0.50$ & $-0.08 \pm 0.66$ & $1.92 * * \pm 0.09$ & $0.42 * * \pm 0.07$ & $-0.35 \pm 0.46$ & $1.11 * * \pm 0.41$ & $-1.81 \pm 1.18$ \\
\hline Number of clusters per plant & $-0.78 \pm 2.84$ & $6.15 \pm 3.76$ & $10.03 * * \pm 0.62$ & $1.40 * * \pm 0.18$ & $-2.69 \pm 2.70$ & - & - \\
\hline Number of pods per cluster & $-0.75 \pm 0.52$ & $1.85 * * \pm 0.57$ & $2.70 * * \pm 0.09$ & $0.06 \pm 0.06$ & $-0.56 \pm 0.41$ & $-1.24 * * \pm 0.37$ & $3.47 * * \pm 1.10$ \\
\hline Number of pods per plant & $-1.31 \pm 10.01$ & $38.12 * * \pm 14.29$ & $26.71 * * \pm 2.16$ & $3.29 * * \pm 0.50$ & $-19.71 \pm 10.17$ & $-19.06 * \pm 8.56$ & $52.58 * \pm 25.88$ \\
\hline Pod length (cm) & $0.03 \pm 0.28$ & $-0.17 \pm 0.44$ & $5.27 * * \pm 0.06$ & $0.26 * * \pm 0.04$ & $0.18 \pm 0.30$ & - & - \\
\hline Number of seed per pod & $-0.81 \pm 0.48$ & $-0.13 \pm 0.62$ & $6.85 * * \pm 0.07$ & $0.06 \pm 0.09$ & $0.85 * \pm 0.42$ & - & - \\
\hline 100-seed weight (g) & $0.76 * * \pm 0.18$ & $0.48 * \pm 0.21$ & $4.20 * * \pm 0.03$ & $-0.01 \pm 0.01$ & $-0.76 * * \pm 0.15$ & $-0.21 \pm 0.13$ & $0.38 \pm 0.41$ \\
\hline MYMV disease score at 45 DAS & $-4.20 * * \pm 0.44$ & $1.94 \pm 1.53$ & $1.29 * * \pm 0.11$ & $2.69 * * \pm 0.05$ & $-4.68 * * \pm 1.03$ & $3.38 * * \pm 0.77$ & $8.18 * * \pm 2.19$ \\
\hline MYMV disease score at 60 DAS & $-1.00 \pm 0.62$ & $3.54 * \pm 1.73$ & $2.38 * * \pm 0.15$ & $3.26^{* *} \pm 0.05$ & $-5.79 * * \pm 1.18$ & $3.99 * * \pm 0.89$ & $6.05^{*} \pm 2.58$ \\
\hline Seed yield per plant (g) & $5.02 * \pm 2.41$ & $14.60 * * \pm 3.75$ & $6.36 * * \pm 0.53$ & $1.14 * * \pm 0.14$ & $-8.89 * * \pm 2.64$ & $-6.61 * * \pm 2.19$ & $12.77 \pm 6.56$ \\
\hline
\end{tabular}

*** Significant at 5 and 1 level of probability, respectively.

Table.3 Scaling test and estimates of genetic parameters for various characters in blackgram the cross MDU1 x Mash 1008

\begin{tabular}{|c|c|c|c|c|c|c|c|}
\hline \multirow[t]{2}{*}{ Character } & \multicolumn{2}{|c|}{ Scales } & \multicolumn{5}{|c|}{ Parameters } \\
\hline & $\mathbf{C}$ & D & $\mathbf{m}$ & d & h & $\mathbf{i}$ & 1 \\
\hline Plant height (cm) & $4.05 \pm 5.08$ & $25.75 * * \pm 4.53$ & $35.30 * * \pm 0.84$ & $5.76 * * \pm 0.61$ & $-16.58 * * \pm 3.39$ & $-4.97 \pm 3.37$ & $28.94 * * \pm 9.86$ \\
\hline Number of branches per plant & $-2.16^{* * \pm 0.54}$ & $0.52 \pm 0.50$ & $1.96 * * \pm 0.10$ & $0.01 \pm 0.07$ & $-0.37 \pm 0.37$ & $-0.69 \pm 0.36$ & $3.57 * * \pm 1.07$ \\
\hline Number of clusters per plant & $-15.41 * * \pm 2.52$ & $2.59 \pm 2.43$ & $9.99 * * \pm 0.38$ & $-0.18 \pm 0.24$ & $1.34 \pm 1.81$ & $-4.65 * * \pm 1.64$ & $24.00 * * \pm 5.03$ \\
\hline Number of pods per cluster & $0.75 * * \pm 0.26$ & $1.98 * * \pm 0.33$ & $3.01 * * \pm 0.06$ & $-0.11 * \pm 0.05$ & $-0.84 * * \pm 0.22$ & $-1.41 * * \pm 0.22$ & $1.63 * * \pm 0.61$ \\
\hline Number of pods per plant & $-41.03 * * \pm 8.09$ & $23.84 * * \pm 7.84$ & $31.40 * * \pm 1.53$ & $-3.57 * * \pm 0.67$ & $-1.29 \pm 5.89$ & $-29.87 * * \pm 5.48$ & $86.49 * * \pm 16.91$ \\
\hline Pod length (cm) & $2.46 * * \pm 0.28$ & $0.00 \pm 0.21$ & $5.40 * * \pm 0.05$ & $0.55 * * \pm 0.02$ & $0.11 \pm 0.17$ & $1.52 * * \pm 0.17$ & $-3.28 * * \pm 0.54$ \\
\hline Number of seed per pod & $1.37 * * \pm 0.44$ & $-0.81 * * \pm 0.30$ & $7.00 * * \pm 0.07$ & $0.35 * * \pm 0.04$ & $0.78 * * \pm 0.24$ & $1.47 * * \pm 0.24$ & $-2.90 * * \pm 0.78$ \\
\hline 100-seed weight (g) & $0.75 * * \pm 0.21$ & $0.30 * \pm 0.13$ & $4.28 * * \pm 0.03$ & $0.17 * * \pm 0.01$ & $-0.11 \pm 0.11$ & $0.26 * \pm 0.11$ & $-0.61 \pm 0.36$ \\
\hline MYMV disease score at 45 DAS & $2.58 * * \pm 0.50$ & $-2.33 * * \pm 0.66$ & $2.99 * * \pm 0.12$ & $2.69 * * \pm 0.05$ & $-0.70 \pm 0.47$ & $7.36 * * \pm 0.43$ & $-6.55 * * \pm 1.26$ \\
\hline MYMV disease score at 60 DAS & $4.84 * * \pm 0.48$ & $0.33 \pm 0.81$ & $3.84 * * \pm 0.12$ & $3.26 * * \pm 0.05$ & $-2.67 * * \pm 0.56$ & $7.11 * * \pm 0.47$ & $-6.02 * * \pm 1.39$ \\
\hline Seed yield per plant (g) & $-7.01 * * \pm 1.66$ & $4.39 * \pm 1.78$ & $7.00 * * \pm 0.38$ & $0.07 \pm 0.15$ & $1.08 \pm 1.32$ & $-3.94 * * \pm 1.25$ & $15.20 * * \pm 3.80$ \\
\hline
\end{tabular}
*** Significant at 5 and 1 level of probability, respectively. 


\section{MYMV disease score at 45 DAS}

The scaling test showed the significance for the scale $\mathrm{C}$ in the cross MDU1 x Mash 114 and both scales in the cross MDU1 x Mash 1008 recorded significance. The additive, dominance, additive $\mathrm{x}$ additive and dominance $\times$ dominance components were significant in the cross MDU1 x Mash 114. In case of MDU1 x Mash 1008, components additive (d), additive $\mathrm{x}$ additive (i) and dominance $\mathrm{x}$ dominance (l) components were significant. The results indicated that additive-dominance and epistatic gene action plays a major role in both crosses.

\section{MYMV disease score at 60 DAS}

The scaling test showed the significance for the scale D and C in the cross MDU1 x Mash 114 and MDU1 x Mash 1008 respectively. The additive (d), dominance (h), additive $x$ additive (i) and dominance $x$ dominance (l) components were significant in both crosses. The results indicated that additive-dominance and epistatic gene action plays a major role in both crosses.

\section{Seed yield per plant (g)}

Significance of the scales C and D implied epistatic model for both crosses. The additive (d), dominance (h) and additive $\mathrm{x}$ additive (i) effects were significant in the cross MDU1 $x$ Mash 114.

The results indicated that additive and epistatic gene action were involved in controlling this trait in MDU1 x Mash 114. In case of MDU1 x Mash 1008 additive $\mathrm{x}$ additive (i) and dominance $\mathrm{x}$ dominance (l) components were significant. The results indicated that epistatic gene action plays a major role in MDU1 x Mash 1008. Nonadditive gene action was reported by Latha $e t$ al., (2018).
To conclude, the cross MDU 1 x Mash 114 recorded simple additive-dominance model for traits viz., number of cluster per plant, pod length and number of seeds per pod. Hence selection at early generation itself will be effective to improve the mean performance of progenies for these traits. Traits viz., plant height, number of branches per plant, number of pods per cluster, MYMV disease score at 45 DAS and 60 DAS and seed yield per plant had both additive as well as additive $\mathrm{x}$ additive gene action. These traits can be improved by selection in later generation. Traits viz., number of pods per cluster and 100 -seed weight had epistatic or dominance gene action. Hence improvement on these traits may not be effective after the selection. In case of MDU 1 x Mash 1008 all traits had epistatic model. Traits viz., plant height, number of pods per cluster, number of pods per plant, pod length, number of seeds per pod, 100-seed weight, MYMV disease score at 45 DAS and 60 DAS had additive as well as additive $\mathrm{x}$ additive gene action. Hence selection should be postponed to later generation to improve these traits. Traits viz., number of branches per plant, number of clusters per plant and seed yield per plant had any epistatic gene action. Hence improvement on these traits may not be effective after selection. Hence the cross MDU 1 x Mash 114 may be used to evolve high yielding MYMV disease resistant genotypes.

\section{References}

Annonymous, 2018. Project Coordinator's Reports (Mungbean and Urdbean), 2017-18. All India Coordinated Research Project on MULLaRP, ICARIndian Institute of Pulses Research, Kanpur-208204, Uttar Pradesh, India, Pp-46.

Gopikannan, M., Ganesh, S. K. 2013. Genetic analysis of sodicity tolerance in rice (Oryza sativa L.). International Journal of Agriculture Environment and 
Biotechnology 6(4): 527-531.

Hayman, B. I. 1958. The separation of epistatic from additive and dominance variation in generation means. Heredity, 12, 371-390.

Kanchana Rani, R. 2008. Genetic studies for improvement of yield and mungbean yellow mosaic virus disease resistance in blackgram. Ph.D. Thesis, Tamil Nadu Agric. Univ., Coimbatore.

Khattak, G.S.S., Haq, M. A., Ashraf, M. and Mc Neilly, T. 2001. Genetic basis of variation in yield and yield components mungbean [Vigna radiata (L.) Wilczek]. Heriditas., 13 (4): 211-217.

Latha Swarna, V., Eswari, K.B. and Sudheer Kumar, S. 2018. Combining ability analysis for seed yield and its component characters in greengram (Vigna radiata (L.) Wilczek.). International J. Chemical Studies L: 6(2): 237-242.

Mangaldeep, S., Dinesh, K.S., Mani, L., Abhijit, K.D., Sankalpa, O. 2015. Exploitation of heterosis and combining ability for earliness and vegetative traits in ridge gourd (Luffa acutangula L.). International Journal of Agriculture, Environment and Biotechnology 8(1): 153-161.

Mather, K. 1949. Biometrical genetics. Methuen and Co. Ltd., London.

Mather, K. and Jinks, J.L. 1971. Biometrical Genetics: The study of continuous variation. Chapman and Hall Ltd., London.

Mehra, R., Tikle, A.N., Saxena, A., Munjal, A., Khandia, R. and Singh, M., 2016.Correlation, path-coefficient and genetic diversity In Blackgram (Vigina mungo (L) Hepper). Internat. Res. J. Plant Sci., 7 (1):001-011.

Nene Y.L. 1972. A survey of the viral diseases of pulse crops in Uttar Pradesh, G.B. Pant University of Agriculture and Technology, Pantnagar, Res. Bull., 4: 191.

Panigrahi, K. K., Mohanty, A., Pradhan, J., Baisakh, B., Kar, M. 2015. Analysis of Combining ability and genetic parameters for yield and other quantitative traits in black gram [Vigna mungo (L.) Hepper]. Legume Genomics and Genetics. $(6,1)$ : 1-11.

Prasad, A.V.S. and Murugan E. 2015. Combining ability analysis for yield and its attributes in Blackgram (Vigna mungo (L.) Hepper). Electronic J. of Plant Bred, 6(2): 417-423.

Singh, S.K., Gupta, B.R. and Chib, H.S. 1995. Relation of plant age with yellow mosaic virus infection in urdbean. In: Gupta VK, Sharma RC (eds) Integrated disease management and plant health. Scientific Publishers, Joypur, pp 91-92

Thamodharan, G., Ramalingam, A. and Geetha, S. 2015. Estimation of genetic parameters and combining ability analysis in blackgram [Vigna mungo (L.) Hepper]. Legume Research, 40(3): 401-408.

Zubair, M., Ajmal, S.U., Munir, M. and Anwar, M. 2007. Mode of inheritance and variability of some of the traits in mungbean [Vigna radiata (L.) Wilczek]. Pak. J. Bot. 39(4): 12371244.

\section{How to cite this article:}

Vadivel, K., N. Manivannan, A. Mahalingam, V.K. Satya, C. Vanniarajan and Saminathan, V.R. 2019. Generation Mean Analysis for Yield, Yield Components and MYMV Disease Scores in Blackgram [Vigna mungo (L).Hepper]. Int.J.Curr.Microbiol.App.Sci. 8(05): 19891995. doi: https://doi.org/10.20546/ijcmas.2019.805.231 